\title{
Early predictors of brain damage in full-term newborns with hypoxic ischemic encephalopathy
}

This article was published in the following Dove Press journal:

Neuropsychiatric Disease and Treatment

8 August 2017

Number of times this article has been viewed

\author{
Usama M Alkholy' \\ Nermin Abdalmonem' \\ Ahmed Zaki \\ Yasser $\mathrm{F} \mathrm{Ali}^{1}$ \\ Soma Abdalla Mohamed ${ }^{3}$ \\ Nasser I Abdelsalam' \\ Mustafa Ismail Abu Hashim' \\ Mohamed Abou Sekkien ${ }^{3}$ \\ Yasser Makram Elsherbiny ${ }^{4}$ \\ 'Pediatric Department, Zagazig \\ University, Egypt; ${ }^{2}$ Pediatric \\ Department, Mansoura University, \\ Egypt; ${ }^{3}$ Pediatric Department, \\ Al Azhar University, Egypt; ${ }^{4}$ Clinical \\ Pathology Department, Menoufia \\ University, Egypt
}

Objective of the study: To evaluate the value of serum creatine phosphokinase-brain specific (CK-BB) and urinary lactate/creatinine $(\mathrm{L} / \mathrm{C})$ ratio as early indicators of brain damage in fullterm newborns with hypoxic ischemic encephalopathy (HIE).

Patients and methods: A case-control study including 25 full-term new-born infants with perinatal asphyxia who were admitted to neonatal intensive care unit (NICU) with a proven diagnosis of HIE, compared to 20 healthy age- and sex-matched full-term newborns. All newborn infants were subjected to full history taking, clinical examination, routine investigations (cord blood gases and complete blood picture), and assessment of serum CK-BB (cord blood, 6 and 24 hours after birth) and urinary L/C ratio (collected within the first 6 hours, on the 2 nd and 3rd day after birth).

Results: The serum CK-BB and urinary L/C ratio in infants with HIE were significantly higher in samples collected throughout the monitoring period when compared with the control group (all $P<0.001$ ). The cord CK-BB and urinary $\mathrm{L} / \mathrm{C}$ ratio within the first 6 hours were significantly higher in infants with severe HIE than in infants with mild and moderate HIE $(P<0.001)$. Cord CK-BB level at $12.5 \mathrm{U} / \mathrm{L}$ had $100 \%$ sensitivity and $84 \%$ specificity in the detection of severe HIE infants. Urinary L/C ratio of more than 10.5 collected within the first 6 hours after birth had $100 \%$ sensitivity and $78 \%$ specificity for the detection of severe HIE infants.

Conclusion: The serum $\mathrm{CK}-\mathrm{BB}$ and urinary $\mathrm{L} / \mathrm{C}$ ratio in $\mathrm{HIE}$ infants were significantly increased early in the course of the disease, which can be used as useful indicators for predicting the development of HIE.

Keywords: hypoxic ischemic encephalopathy, biomarkers, urinary lactate, serum CKBB, neonatal morbidity

\section{Introduction}

Perinatal asphyxia is a major cause of neonatal morbidity and mortality in the neonatal period and long-term neurologic disabilities among survivors. ${ }^{1}$ The incidence of hypoxic ischemic encephalopathy (HIE) among full-term newborns is $1-4 / 1,000 .^{2}$ About $20 \%-50 \%$ of HIE infants die early in life and $25 \%-60 \%$ of the survivors suffer from permanent neurologic disabilities, including cerebral palsy, epilepsy, mental retardation, and learning defects. ${ }^{3,4}$ Newborns who developed severe perinatal asphyxia and suffer fetal acidemia, require intensive resuscitation, and showed an abnormal EEG are at highest risk for HIE complications. ${ }^{5,6}$ Several biomarkers were done for proper assessment of the severity of brain damage. An ideal biomarker for the diagnosis of HIE should be specific, early, rapid, and easily done. The results of these biomarkers should be interpreted in conjunction with the clinical history and physical examination. ${ }^{7,8}$

Creatine phosphokinase-brain specific (CK-BB) is found in both neurons and astrocytes and its level was detected to be higher in infants exposed to perinatal
Correspondence: Usama M Alkholy

Pediatric Department, Zagazig

University, Egypt

Tel +966550491948

Email usamaalkoly@yahoo.com
Neuropsychiatric Disease and Treatment 2017:13 2133-2139

cc) (i) (2) () 2017 Alkholy et al. This work is published and licensed by Dove Medical Press Limited. The full terms of this license are avalable at https://www.dovepress.com/terms.php cc. hereby accept the Terms. Non-commercial uses of the work are permitted without any further permission from Dove Medical Press Limited, provided the work is properly attributed. For permision for commercial use of this work, please see paragraphs 4.2 and 5 of our Terms (https://www.doveperess. com/terms.php). 
asphyxia. ${ }^{9}$ Its serial serum-level assessment after birth and its role in the early detection of HIE have not been well studied. ${ }^{10,11}$

Lactate is produced by anerobic oxidation during an asphyxia insult and continues to be excreted via the kidney for a long period after the insult so that measurement of urinary lactate may reflect the blood lactate level and the degree of metabolic derangement as a result of hypoxia/ischemia. ${ }^{12}$ Plasma creatinine levels at birth are greatly elevated in relation to the size of the newborn infant and remain so for 1-2 weeks. This may be secondary to the maternal transfer of creatinine or a decreased glomerular filtration rate early in life. ${ }^{13}$ The aim of the study was to investigate the role of serum $\mathrm{CK}-\mathrm{BB}$ and urinary lactate/creatinine $(\mathrm{L} / \mathrm{C})$ ratio as early predictors of HIE in full-term newborn infants and to evaluate their sensitivity and specificity for the early identification of HIE infants.

\section{Patients and methods}

A prospective longitudinal case-control study including 25 full-term infants with a proven diagnosis of HIE who were admitted to neonatal intensive care unit (NICU) in Al-Jedaani Hospital, Jeddah, Saudi Arabia, from November 2014 to October 2016. HIE patients were classified into three groups according to Sarnat and Sarnat staging: ${ }^{14}$ Group A: included 10 cases with mild HIE; Group B: included 8 cases with moderate HIE; Group C: included 7 cases with severe HIE.

\section{Control group}

Twenty healthy full-term newborns with their age and sex matched were included in the study. Ethical approval was obtained from the local research ethics committee from Al Jaddani and Ibn Sina Medical College Hospitals, Jeddah, Saudi Arabia, and the parents of all neonates gave an informed written consent prior to the study.

\section{Exclusion criteria}

Full-term newborns with maternal drug intake, congenital anomalies, or tumors, congenital or perinatal infections, asphyxiated newborns not passing urine in the first 6 hours after birth, and infants with renal impairment were all excluded from the study.

All studied neonates were subjected to the following:

1. History taking including maternal age, parity, gravidity, acute or chronic medical illness, mode of delivery, prolonged labor, the presence of neonatal cyanosis, bradycardia, or delayed first cry.
2. Clinical assessment including Apgar score and a full neurological examination according to Sarnat and Sarnat staging.

3. Laboratory investigations were done including cord blood gases, complete blood picture, and $\mathrm{C}$ reactive protein. ${ }^{15}$

4. Blood samples for CK-BB were taken from the umbilical cord at birth and from the serum 6 and 24 hours after birth. To quantify CK-BB, the isoenzymes were fractionated electrophoretically on agarose gels, visualized by in-gel substrate reaction for fluorometric scanning using Helena (Greiner, Flacht, and Germany) gel kits and the rapid electrophoresis system. The area under the CK-BB curve was used to calculate its concentration.

5. Measurement of urinary $\mathrm{L} / \mathrm{C}$ ratio.

Urine samples were collected within the first 6 hours after birth and 24 and 48 hours after birth. Urine samples were collected and immediately centrifuged at $900 \times \mathrm{g}$ for 10 minutes, and stored at $-70^{\circ} \mathrm{C}$. Urinary lactate can be measured by the conventional enzymatic method by a Randox ${ }^{\mathrm{TM}}$ kit (Randox Laboratories, Co., Antrim, UK) on Olympus auto-analyzer (Olympus Corporation, Tokyo, Japan). ${ }^{16}$ Creatinine in urine was measured by the concentration of an yellow orange-colored dye formed from the reaction with Picric acid under alkaline conditions, which had its absorption maximum at $500 \mathrm{~nm}$.

\section{Statistical analysis}

Data were statistically analyzed with the Statistical Package for Social Sciences version 21. Data were presented as mean \pm SD or percentage. The mean values of two groups were compared using Student's $t$-test and more than two groups using the one-way ANOVA test with post hoc Tukey test. Linear correlation was used to test the correlation between the measured parameters. Receiver operating characteristic (ROC) curves were constructed for CK-BB and urinary $\mathrm{L} / \mathrm{C}$ ratio to measure sensitivity and specificity to detect severe HIE infants. $P$-values $<0.05$ were considered significant.

\section{Results}

1. Demographic characteristics of the studied groups: No significant differences were present between both groups in regard to birth weight or gender. The Apgar scores at 1,5 , and 10 minutes were significantly lower in the patients' group compared to the control group $(P<0.001)$. Clinically, lethargy, seizures, and poor feeding were found in 60\% (15 cases) of cases. Cyanosis, decreased tone, and respiratory distress were found 
Table I Demographic characteristics of the studied newborns

\begin{tabular}{|c|c|c|c|c|}
\hline Variable & $\begin{array}{l}\text { HIE group } \\
(n=25)\end{array}$ & $\begin{array}{l}\text { Control group } \\
(n=20)\end{array}$ & $t / \chi^{2}$ & $P$-value \\
\hline \multicolumn{5}{|l|}{ Gestational age (weeks) } \\
\hline$X \pm S D$ & $39.2 \pm I .24(37-4 I)$ & $39.15 \pm 1.23(37-42)$ & 0.47 & 0.65 \\
\hline \multicolumn{5}{|l|}{ Birth weight (kg) } \\
\hline$X \pm S D$ range & $3.1 \pm 0.4(2.4-3.9)$ & $3.01 \pm 0.36(2.5-3.8)$ & 0.59 & 0.56 \\
\hline \multicolumn{5}{|l|}{ Gender (n, \%) } \\
\hline Male & $10(40.0)$ & $7(35.0)$ & $\chi^{2}=0.11$ & 0.74 \\
\hline Female & $15(60.0)$ & $13(56.0)$ & & \\
\hline \multicolumn{5}{|l|}{ Mode of delivery } \\
\hline Vaginal delivery & $12(48.0)$ & $9(45.0)$ & 6.67 & 0.19 \\
\hline Cesarean section & $13(52.0)$ & II (55.0) & & \\
\hline \multicolumn{5}{|l|}{ Apgar score } \\
\hline I minute $X \pm S D$ range & $2.0 \pm 1.7(0-4)$ & $8.53 \pm 0.8(7-10)$ & 15.66 & $<0.001$ \\
\hline 5 minute $X \pm S D$ range & $3.48 \pm 1.4(I-7)$ & $8.95 \pm 0.8(8-10)$ & 14.12 & $<0.001$ \\
\hline 10 minute $X \pm S D$ range & $5.15 \pm 1.4(3-8)$ & $9.95 \pm 0.2(9-10)$ & 12.11 & $<0.001$ \\
\hline \multicolumn{5}{|l|}{ Clinical signs } \\
\hline Lethargy & $15(60 \%)$ & Free & & \\
\hline Seizures & $15(60 \%)$ & & & \\
\hline Poor feeding & $15(60 \%)$ & & & \\
\hline Cyanosis & $10(40 \%)$ & & & \\
\hline Respiratory distress & $10(40 \%)$ & & & \\
\hline Decreased tone & $10(40 \%)$ & & & \\
\hline Hypertonia & $5(20 \%)$ & & & \\
\hline
\end{tabular}

Abbreviation: HIE, hypoxic ischemic encephalopathy.

in $40 \%$ (10 cases) and hypertonia in $20 \%$ of patients (5 cases) (Table 1$)$.

2. Laboratory characteristics of the studied groups:

White blood cell count was significantly higher and the platelet count was significantly lower in the patient group when compared to the control group $(P<0.001)$. The mean cord $\mathrm{pH}$ values, base excess, and $\mathrm{PO}_{2}$ were significantly lower in asphyxiated infants than in controls, while the mean $\mathrm{PCO}_{2}$ were significantly higher $(P<0.001)$ (Table 2).

a. The mean urinary $\mathrm{L} / \mathrm{C}$ ratios measured within the first 6 hours and in the second and third days were significantly higher in the asphyxiated infants when compared to the control group $(7.56 \pm 2.80,1.96 \pm 1.18$, and $1.96 \pm 1.18$ versus $0.26 \pm 0.12,0.22 \pm 0.08$, and $0.15 \pm 0.07, P<0.05$, respectively; Table 2 ). It was significantly higher in infants with severe asphyxia compared to both infants with mild and moderate asphyxia $(P<0.05$; Table 3$)$.

b. The mean serum CK-BB was significantly higher in asphyxiated infants compared to the control group when measured in the cord blood and at 6 and 24 hours after birth $(10.2 \pm 3.7,10.8 \pm 3.9$, and $7.9 \pm 4.6$ versus $3.0 \pm 2.6,5.5 \pm 2.8$, and $4.5 \pm 1.8, P<0.05$, respectively). (Table 2). Also, CK-BB was significantly higher in infants with severe asphyxia compared to both infants with mild and moderate asphyxia $(P<0.05$; Table 3).

3. Correlation between urinary $\mathrm{L} / \mathrm{C}$ ratio and serum $\mathrm{CK}-\mathrm{BB}$ with Apgar scores and cord blood gases.

Table 2 Laboratory investigations of the studied groups

\begin{tabular}{|c|c|c|c|c|}
\hline Parameter & $\begin{array}{l}\text { HIE group } \\
(\mathrm{n}=25)\end{array}$ & $\begin{array}{l}\text { Control } \\
\text { group }(n=20)\end{array}$ & $t$ & $P$-value \\
\hline Hematocrit value (\%) & $46.65 \pm 6.61$ & $48.4 I \pm 8.2 I$ & 0.28 & 0.12 \\
\hline Platelet count $\left(\times 10^{3} / \mathrm{mm}^{3}\right)$ & $156.0 \pm 69$ & $200.7 \pm 69$ & 15.9 & $<0.001$ \\
\hline $\begin{array}{l}\text { White blood cell count } \\
\left(\times 10^{3} / \mathrm{mm}^{3}\right)\end{array}$ & $21.93 \pm 15.06$ & $14.13 \pm 8.34$ & 7.3 & $<0.001$ \\
\hline \multicolumn{5}{|l|}{ Cord blood gases } \\
\hline $\mathrm{pH}$ & $7.0 \pm 0.15$ & $7.33 \pm 0.05$ & 5.43 & $<0.001$ \\
\hline Base excess (mmol/L) & $-15.6 \pm 3.6$ & $-3.7 \pm 2.19$ & 11.52 & $<0.001$ \\
\hline $\mathrm{PO}_{2}(\mathrm{mmHg})$ & $22.5 \pm 6.4$ & $28.58 \pm 4.5$ & 3.49 & $<0.01$ \\
\hline $\mathrm{PCO}_{2}(\mathrm{mmHg})$ & $65.5 \pm 13.8$ & $38.4 I \pm 4.68$ & 5.33 & $<0.01$ \\
\hline \multicolumn{5}{|l|}{ Serum CK-BB U/L } \\
\hline Cord blood & $10.2 \pm 3.7$ & $3.0 \pm 2.6$ & 9.1 & $<0.001$ \\
\hline 6 hours after delivery & $10.8 \pm 3.9$ & $5.5 \pm 2.8$ & 9.6 & $<0.001$ \\
\hline 24 hours after delivery & $7.9 \pm 4.6$ & $4.3 \pm 1.8$ & 4.9 & 0.026 \\
\hline \multicolumn{5}{|l|}{ Urinary L/C ratio } \\
\hline In first 6 hours & $7.56 \pm 2.80$ & $0.26 \pm 0.10$ & 9.6 & $<0.001$ \\
\hline After 24 hours & $1.96 \pm 1.18$ & $0.22 \pm 0.08$ & 4.5 & $<0.05$ \\
\hline After 48 hours & $1.49 \pm 0.68$ & $0.15 \pm 0.07$ & 3.6 & $<0.05$ \\
\hline
\end{tabular}

Abbreviations: HIE, hypoxic ischemic encephalopathy; CK-BB, creatine phosphokinase-brain specific; L/C, lactate/creatinine. 
Table 3 Comparison between indicators of hypoxia according to the degree of HIE

\begin{tabular}{lllll}
\hline Variable & $\begin{array}{l}\text { Group A } \\
\text { no }=1 \mathbf{0}\end{array}$ & $\begin{array}{l}\text { Group B } \\
\text { no }=8\end{array}$ & $\begin{array}{l}\text { Group C } \\
\text { no }=\mathbf{7}\end{array}$ & P-value \\
\hline Apgar I minute & $3.1 \pm 0.567^{\mathrm{A}, \mathrm{C}}$ & $1.87 \pm 0.64^{\mathrm{B}, \mathrm{C}}$ & $0.7 \mathrm{I} \pm 0.75^{\mathrm{A}, \mathrm{B}}$ & $<0.00 \mathrm{I}$ \\
Apgar 5 minutes & $4.7 \pm 0.94^{\mathrm{D}, \mathrm{F}}$ & $3.25 \pm 0.88^{\mathrm{E}, \mathrm{F}}$ & $2.0 \pm 1.0^{\mathrm{D}, \mathrm{E}}$ & $<0.00 \mathrm{I}$ \\
Apgar I0 minutes & $6.3 \pm 1.05^{\mathrm{H}, \mathrm{J}}$ & $4.87 \pm 0.99^{\mathrm{I}, \mathrm{J}}$ & $3.5 \pm 0.53^{\mathrm{H}, \mathrm{I}}$ & $<0.00 \mathrm{I}$ \\
Cord blood pH & $7.15 \pm 0.1^{\mathrm{K}, \mathrm{M}}$ & $6.93 \pm 0.05^{\mathrm{L}, \mathrm{M}}$ & $6.85 \pm 0.05^{\mathrm{K}, \mathrm{L}}$ & $<0.00 \mathrm{I}$ \\
Urinary L/C ratio & $4.2 \pm 1.0^{\mathrm{N}}$ & $8.4 \pm 1.2^{\circ}$ & $12.7 \pm 2.5^{\mathrm{N}, \mathrm{O}}$ & $<0.00 \mathrm{I}$ \\
Cord CK-BB U/L & $6.1 \pm 3.6^{\mathrm{P}}$ & $10.3 \pm 1.6^{\mathrm{Q}}$ & $13.0 \pm 2.9^{\mathrm{P}, \mathrm{Q}}$ & $<0.00 \mathrm{I}$ \\
\hline
\end{tabular}

Notes: Group A: mild HIE; Group B: moderate HIE; Group C: severe HIE. Similar letters indicate significant differences between groups. Use of same superscripted letters indicates significant differences between the two groups only, $P<0.05$.

Abbreviations: HIE, hypoxic ischemic encephalopathy; L/C, lactate/creatinine; CK$\mathrm{BB}$, creatine phosphokinase-brain specific.

4. Both cord CK-BB and urinary $\mathrm{L} / \mathrm{C}$ ratio (1st sample) showed a significant negative correlation with an Apgar score at 1,5 , and 10 minutes, cord blood $\mathrm{pH}$, base excess, and $\mathrm{PO}_{2}(P<0.05)$ and a significant positive correlation with cord blood $\mathrm{PCO}_{2}(P<0.001$; Table 4, Figures 1 and 2$)$.

5. In order to determine the diagnostic capability of the first CK-BB and urinary $\mathrm{L} / \mathrm{C}$ ratio samples assay in the diagnosis of severe HIE, 2 ROC curves were conducted (Figure 3).

For cord CK-BB, area under the curve $(95 \% \mathrm{CI})$ reached $0.96(0.75-1)$ with the best cutoff value being $\geq 12.5 \mathrm{U} / \mathrm{L}$ and had $100 \%$ sensitivity and $84 \%$ specificity in the diagnosis of severe HIE cases. For urinary L/C ratio in the first 6 hours, area under the curve $(95 \% \mathrm{CI})$ reached $0.95(0.76-1)$ with the best cutoff value being $\geq 10.5$ and had $100 \%$ sensitivity and $78 \%$ specificity for the detection of severe cases of HIE.

\section{Discussion}

Brain damage following asphyxia may be subclinical or hidden by the effect by sedation. Early detection may be

Table 4 Correlation between urinary L/C ratio and serum CK-BB with other parameters in the asphyxiated group

\begin{tabular}{llllll}
\hline & \multicolumn{2}{l}{ Urinary L/C ratio } & & \multicolumn{2}{c}{ Serum CK-BB } \\
\cline { 2 - 3 } \cline { 5 - 6 } & $\boldsymbol{R}$ & P-value & & $\boldsymbol{R}$ & P-value \\
\hline Apgar score, minute & & & & \\
I & -0.84 & $<0.001$ & & -0.79 & $<0.001$ \\
5 & -0.70 & $<0.001$ & & -0.7 & 0.019 \\
I0 & -0.79 & $<0.001$ & & -0.78 & 0.004 \\
Cord blood gases & & & & \\
pH & -0.78 & $<0.001$ & -0.78 & $<0.001$ \\
Base excess & -0.55 & $<0.01$ & -0.48 & $<0.05$ \\
$\mathrm{PO}_{2}$ & -0.48 & $<0.05$ & -0.49 & $<0.01$ \\
$\mathrm{PCO}_{2}$ & 0.64 & $<0.001$ & 0.68 & $<0.001$ \\
\hline
\end{tabular}

Note: $P<0.00$ I: highly significant.

Abbreviations: L/C, lactate/creatinine; CK-BB, creatine phosphokinase-brain specific. difficult even with close clinical monitoring. Furthermore, radiological assessment is not sensitive enough for early detection of HIE. ${ }^{17}$ Assessment of brain-specific biochemical markers for detection of early brain damage changes could be especially useful in the proper management of brain injury.

The birth weight and sex in our study showed no significant differences between asphyxiated infants and the controls. The same results were detected by Florio et al, ${ }^{18}$ while Bang et al found that LBW infants are susceptible to develop asphyxia due to low metabolic reserves and cannot tolerate perinatal asphyxia. ${ }^{19}$

The Apgar scores at 1, 5, and 10 minutes were significantly lower in the asphyxiated infants compared to the control group. The same result was detected by Boskabadi et al that found a lower Apgar score at 1 and 5 minutes postpartum, which is considered as an indicator of exposure to perinatal asphyxia. ${ }^{20}$ However, Freeman and Nelson reported that an Apgar score at 1 minute indicates neither substantial hypoxia nor ischemia. ${ }^{21}$ Basu et al reported that the best index for perinatal asphyxia is an Apgar score at 5 minutes. ${ }^{22}$ Despite all these results, a low Apgar score is still not specific for perinatal asphyxia. ${ }^{23}$

In the present study, the cord blood $\mathrm{pH}$, base excess, and $\mathrm{PO}_{2}$ were significantly lower, while $\mathrm{PCO}_{2}$ was significantly higher in asphyxiated infants compared to controls. Umbilical artery $\mathrm{pH}<7.00$ was detected to be of bad prognostic criteria. ${ }^{24-26}$ The decision to only depend on blood gas analysis is determined by the following doctors. ${ }^{27}$

In our study, the mean values of urinary $\mathrm{L} / \mathrm{C}$ ratio in the asphyxiated newborn infants at 6,24, and 48 hours after birth were significantly higher compared to the control group. Our results were in agreement with Huang et al who found that within 6 hours after birth, the mean ratio of urinary $\mathrm{L} / \mathrm{C}$ was higher in HIE infants in comparison with normal infants. ${ }^{28}$ Another study found a higher urinary $\mathrm{L} / \mathrm{C}$ ratio in HIE infants and this study was done after 24 hours from delivery to avoid delayed urination that may occur after birth. ${ }^{29}$ In our study, we excluded any HIE infants not passing urine in the first 6 hours from the start to avoid this problem. Also, Ghotbi and Najibi reported a higher urinary $\mathrm{L} / \mathrm{C}$ ratio in HIE infants within the first 6 hours after birth, which was 11-fold greater than the control group, and this ratio decreased to become 5-fold 24 hours after birth. ${ }^{30}$ Another study by Abdulqawi et al considered that the urinary $\mathrm{L} / \mathrm{C}$ ratio was a good predictor for HIE especially if combined with the HIE scoring system, cord blood gases, and cranial ultrasonography. ${ }^{31}$ But, one study reported that the urinary $\mathrm{L} / \mathrm{C}$ ratio is not a good indicator of brain injury as lactate is a global marker of anerobic 


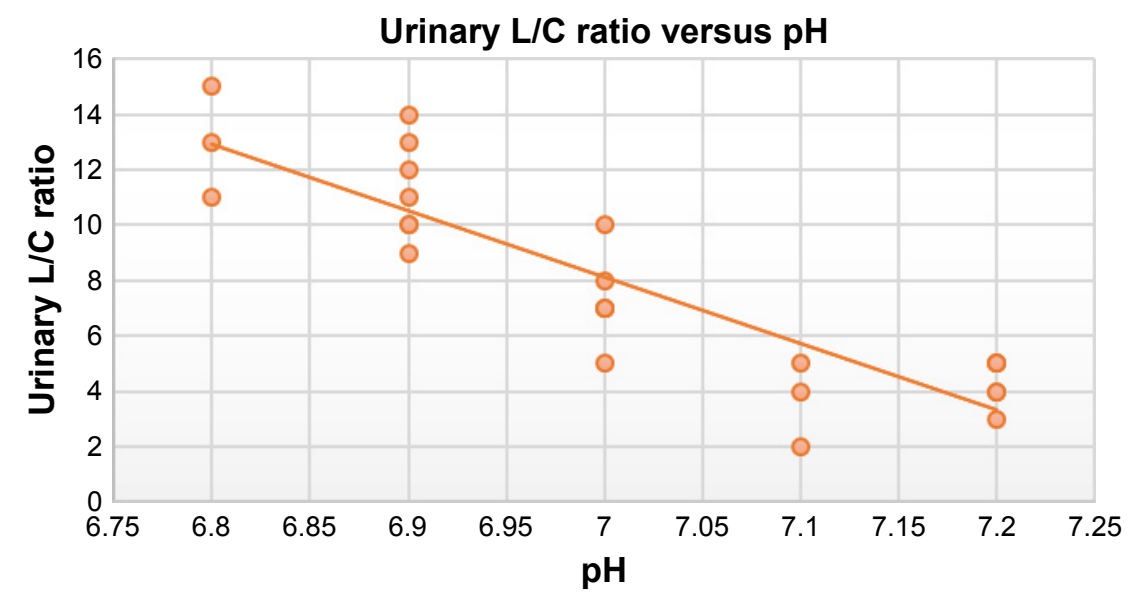

Figure I Correlation between urinary $\mathrm{L} / \mathrm{C}$ ratio and cord blood $\mathrm{pH}$.

Abbreviation: L/C, lactate/creatinine.

metabolism and would not be brain-specific. ${ }^{32}$ But, our patients do not have renal impairment from the start thus excluding an important cause of elevated lactate. The systemic hypoxia affecting the brain, skeletal muscle, and/or kidney is the main source of lactate in urine. ${ }^{33,34}$

In the present study, the mean value of serum CK-BB in the cord blood, after 6 and 24 hours in the asphyxiated infants were significantly higher than in the control group. Although Sweet et al who studied 97 babies with perinatal asphyxia reported higher CK-BB in asphyxiated cases than control, they found CK-BB $>21 \mathrm{IU} / \mathrm{L}$ had a low specificity $40 \%$. So, they considered CK-BB as not a useful marker for prediction of the neurological results of perinatal asphyxia. ${ }^{35}$ Fernandez et al reported that an elevated CK-BB activity at the 4th and 10th hour after birth is a good marker for brain damage and documented that infants who died of severe HIE or developed neurologic sequelae had significantly higher serum CK-BB activities than babies who did not have neurological abnormalities. ${ }^{9}$ Prithviraj et al reported a higher CK-BB in cases of HIE compared to controls in a study that included 80 babies with perinatal asphyxia. Also, they found in their study that 10 infants died within 72 hours after birth and they had higher serum CK-BB activities. ${ }^{36}$ The serum CK-BB in full-term newborns with high-risk pregnancy was higher in comparison with babies with normal pregnancy. ${ }^{37}$

In this study, serum CK-BB and urinary $\mathrm{L} / \mathrm{C}$ ratio levels became lower after 24 hours of birth when compared with the value in the first 6 hours after delivery, which was documented by other studies. ${ }^{30,38}$ This can be explained by a decrease in the serum level of CK-BB and lactate as a result of good management of the HIE infants. ${ }^{39}$

In the present study, the serum CK-BB and urinary L/C ratio showed a significant difference between different groups of study, as both were higher in infants with severe hypoxia in comparison with infants with mild and moderate hypoxia. This finding was confirmed in previous studies that found a correlation between different severities of HIE infants depending on clinical examination and blood gases with the

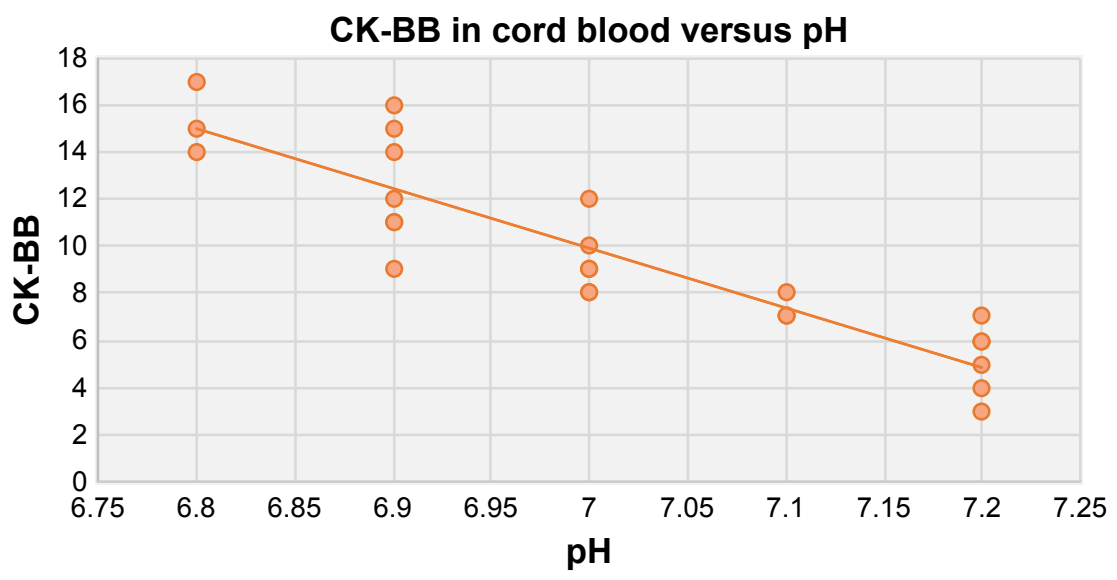

Figure 2 Correlation between serum CK-BB and cord blood $\mathrm{pH}$. Abbreviation: CK-BB, creatine phosphokinase-brain specific. 


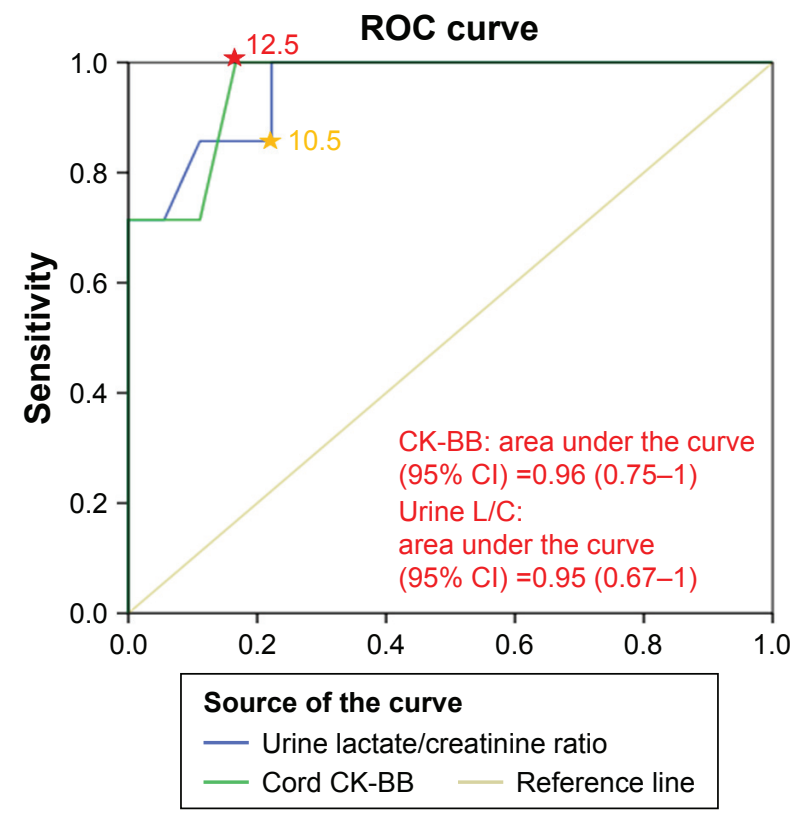

Figure 3 ROC curve study showed that the urinary L/C ratio at 10.5 has $100 \%$ sensitivity and $78 \%$ specificity and serum CK-BB at $12.5 \mathrm{U} / \mathrm{L}$ has $100 \%$ sensitivity and $84 \%$ specificity for detecting severe cases of HIE.

Abbreviations: L/C, lactate/creatinine; CK-BB, creatine phosphokinase-brain specific; $\mathrm{HIE}$, hypoxic ischemic encephalopathy; ROC, receiver operating characteristic.

elevated levels of serum CKBB and urinary L/C ratio early after birth. ${ }^{9,29,30,36}$ There was a case report about an infant that had a very high CK-BB $>26.000 \mathrm{IU} / \mathrm{L}$ and that developed some neurodevelopmental delay in spite of receiving brain hypothermic therapy. ${ }^{40}$ Against our study, Huang et al found a nonsignificant trend for the urinary $\mathrm{L} / \mathrm{C}$ ratio to increase with the severity of the HIE. ${ }^{28}$

In this study, the first sample of both the serum CK-BB and urinary $\mathrm{L} / \mathrm{C}$ ratio showed a significant negative correlation with the cord blood $\mathrm{pH}$, base excess, $\mathrm{PO}_{2}$, and Apgar score in the 1st, 5th, and 10th minute of life and positive correlation with $\mathrm{PCO}_{2}$. Ojha et al found higher urinary $\mathrm{L} / \mathrm{C}$ ratios in babies with meconium staining and considered this result as an indicator of perinatal asphyxia. ${ }^{41}$

Other studies found an almost similar sensitivity and specificity to our results either alone or in combination. Nagdyman et al found that serum protein S-100 (cutoff value, $8.5 \mu \mathrm{g} / \mathrm{L}$ ) and CK-BB (cutoff value, $18.8 \mathrm{U} / \mathrm{L}$ ) 2 hours after birth had the highest predictive value (83\%) and specificity $(95 \%) .{ }^{42}$ Another study reported that the urinary $\mathrm{L} / \mathrm{C}$ ratio at a cutoff value of 0.48 had a sensitivity of $96.1 \%$ and a specificity of $100 \%$ for predicting moderate and severe HIE. ${ }^{30}$ Another study found that in the first 24 hours after delivery the L/C ratio showed the highest sensitivity (91.5\%) and specificity (90.3\%) in predicting moderate to severe HIE. ${ }^{38}$ Yet another study found that the sensitivity and specificity of serum CK-BB for the detection of severe HIE were $87 \%$ and $94 \%$, respectively, in combination with serum lactate, $\mathrm{LDH}$, and uric acid. ${ }^{43}$ The lower specificity of our biomarkers in comparison with other results was explained by detecting severe cases in contrast to other studies detecting moderate and severe cases.

We considered the serum CK-BB and urinary L/C ratio as good biomarkers for evaluation of brain injury because of an earlier diagnosis of HIE within the first 6 hours, their correlations with the degree of HIE, and higher sensitivity and specificity for both that allow for early proper management. Also, the urinary $\mathrm{L} / \mathrm{C}$ ratio measuring test is simple, rapid, noninvasive, and of low cost.

\section{Conclusion}

The serum CK-BB and urinary $\mathrm{L} / \mathrm{C}$ ratio in newborn infants with asphyxia are good early indicators of HIE as well as for assessing the severity of the brain damage and therefore useful in identifying HIE infants that need early proper management. Therefore, we recommend further studies on a large number of cases to correlate between their levels at birth and later growth and development.

\section{Disclosure}

The authors report no conflicts of interest in this work.

\section{References}

1. Chiesa C, Pellegrini G, Panero A, et al. Umbilical cord interleukin-6 levels are elevated in term neonates with perinatal asphyxia. Eur J Clin Invest. 2003;33(4):352-358.

2. Vannucci RC. Hypoxic-ischemic encephalopathy. Am J Perinatol. 2000;17(3):113-120.

3. Derganc M, Osredkar D. Hypoxic-ischemic brain injury in the neonatal period. Zdrav Vestn. 2008;77(Suppl 2):51-54.

4. Miller SP, Ramaswamy V, Michelson D, et al. Patterns of brain injury in term neonatal encephalopathy. J Pediatr. 2005;146(4):453-460.

5. Synder EY, Aurora S. Perinatal asphyxia. In: Cloherty JP, Eichenwald EC, Stark AR, editors. Manual of Neonatal Care. 5th ed. Philadelphia, PA: Lippincott Williams \& Wilkin; 2004:536-555.

6. Volpe JJ. Hypoxic ischemic encephalopathy. In: Soul JS, Robertson RL, Tzika AA, Plessis AJ, Volpe JJ, editors. Neurology of the Newborn. 4th ed. Philadelphia, PA: WB Saunders Co; 2001:217-294.

7. Shankaran SRD, Laptook AR. Hypoxic-ischemic encephalopathy in infants. BMJ. 2010;340-397.

8. Maria DP, Marro PJ. Biochemical basis of hypoxic-ischemic encephalopathy. Am Acad of Pediatr. 2010;11(4):184-193.

9. Fernandez F, Verdu A, Quero J, et al. Serum CKP-BB isoenzyme in the assessment of brain damage in asphyxiated term infants. Acta Pediatr Scand. 1987;76(6):914-918.

10. Garcia-Alix A, Cabanas F, Pellicer A, Hernanz A, Stiris TA, Quero J. Neuron-specific enolase and myelin basic protein: relationship of cerebrospinal fluid concentrations to the neurologic condition of asphyxiated full-term infants. Pediatrics. 1994;93(2):234-240.

11. Thornberg E, Thiringer K, Hagberg H, Kjellmer I. Neuron specific enolase in asphyxiated newborns: association with encephalopathy and cerebral function monitor trace. Arch Dis Child Fetal Neonatal Ed. 1995;72(1):F39-F42. 
12. Shah S, Tracy M, Smyth J. Postnatal lactate as an early predictor of short-term outcome after intrapartum asphyxia. J Perinatol. 2004; 24(1):16-20.

13. Selway LD. State of the science: hypoxic ischemic encephalopathy and hypothermic intervention for neonates. Adv Neonatal Care J. 2010; 10(2):60-66

14. Sarnat HB, Sarnat MS. Neonatal encephalopathy following fetal distress: a clinical and electroencephalographic study. Arch Neurol J. 1976;33(10):696-705.

15. Jaye DL, Waites KB. Clinical applications of C-reactive protein in pediatrics. Pediatr Infect Dis J. 1997;16(8):735-746.

16. Oh W, Perritt R, Shankaran S, Merritts M, et al. Association between urinary lactate to creatinine ratio and neurodevelopmental outcome in term infants with hypoxic-ischemic encephalopathy. J Pediatr. 2008; 153(3):375-378.

17. Khreisa WH, Habahbeh Z. Risk factors of birth asphyxia: a study at Prince Ali Ben Al Hussein hospital, Jordon. Pak J Med Sci. 2005; 21(1):30-34.

18. Florio P, Luisi S, Bruschettini M, et al. Cerebrospinal Fluid Activin A measurement in asphyxiated full-term newborns predicts hypoxic ischemic encephalopathy. Clin Chem J. 2004;50(12):2386-2389.

19. Bang AT, Bang RA, Baitule SB, Reddy HM, Deshmukh MD. Management of birth asphyxia in home deliveries in rural Gadchiroli: the effect of two types of birth attendants and of resuscitating with mouth-to-mouth, tube-mask or bag-mask. J Perinatol. 2005;25(Suppl 1): S82-S91.

20. Boskabadi H, Maamouri G, Sadeghian MH, et al. Early diagnosis of perinatal asphyxia by nucleated red blood cell count: A case-control study. Arch Iran Med. 2010;13(4):275-281.

21. Freeman JM, Nelson KB. Intra-partum asphyxia and cerebral palsy. Pediatrics. 1988;82(2):240-249.

22. Basu P, Som S, Choudhuri N, Das H. Correlation between Apgar score and urinary uric acid to creatinine ratio in perinatal asphyxia. Indian Clin Biochem J. 2008;23(4):361-364.

23. Finster M, Wood M. The Apgar score has survived the test of time. Anesthesiology. 2005;102(4):855-857.

24. Van den Berg PP, Nelen WL, Jongsma HW, et al. Neonatal complications in newborns with an umbilical artery $\mathrm{pH}<7.00$. Am J Obstet Gynecol. 1996;175(5):1152-1157.

25. Loh SF, Woodworth A, Yeo GS. Umbilical cord blood gas analysis at delivery. Singapore Med J. 1998;39(4):151-155.

26. Gregorio HO, Rojas DM, Spilsbury MA, et al. Importance of blood gas measurements in perinatal asphyxia and alternatives to restore the acid base balance status to improve the newborn performance. Am J Biochem Biotechnol. 2007;3(3):131-140.

27. Neilson JP. Umbilical cord blood gas analysis. BMJ. 2010;340:c1720.

28. Huang CC, Wang ST, Chang YC, Lin KP, Wu PL. Measurement of the urinary lactate/creatinine ratio for the early identification of newborn infants at risk for hypoxic-ischemic encephalopathy. $N$ Engl J Med. 1999;341(5):328-335.
29. Kankane A, Kankane A, Tripathi PR. Urinary lactate to creatinine ratio in neonates with perinatal asphyxia and its correlation with severity of hypoxic ischemic encephalopathy. Int J Pediatr Res. 2016;3: $159-164$.

30. Ghotbi N, Najibi B. Measurement of the urinary lactate/creatinine ratio for early diagnosis of the hypoxic-ischemic encephalopathy in newborns. Iran J Pediatr. 2010;20(1):35-40.

31. Abdulqawi K, Al-Zohairy YZ, Karam K. Early Predictors of Neurodevelopmental Adverse Outcome in Term Infants with Postasphyxial Hypoxic Ischemic Encephalopathy. Int J Collaborative Res Intern Med Pub Health. 2011;3(11):822-837.

32. Ramaswamy V, Horton J, Vandermeer B, Buscemi N, Miller S, Yager J. Systematic review of biomarkers of brain its timing, duration, and outcomes are poorly defined injury in term neonatal encephalopathy. Pediatr Neurol. 2009;40(3):215-226.

33. Volpe JJ, editor. Hypoxic-Ischemic encephalopathy: Biochemical and Physiological Aspects. In: Neurology of the Newborn. 5th ed. Philadelphia, PA: Elsevier Science; 2008:247-324.

34. Walker V, Mills GA. Effects of birth asphyxia on urinary organic acid excretion. Biol Neonate. 1992;61(3):162-172.

35. Sweet DG, Bell AH, McClure G, Wallace IJ, Shields MD. Comparison between creatine kinase brain isoenzyme (CKBB) activity and Sarnat score for prediction of adverse outcome following perinatal asphyxia. J Perinat Med. 1999;27(6):478-483.

36. Prithviraj D, Reddy B, Deepthi, et al. A Laboratory findings and clinical correlation in assessing the severity of perinatal asphyxia. Int $J \mathrm{Sci}$ Study. 2016;4(1).

37. Khan A, Rathore B, Singh K, Singh M, Misra A. Association of creatine kinase and its isoenzymes (CK-MB, CK-BB) activity with high risk pregnancy. Int J Res Med Sci. 2017;5(4):1464-1470.

38. Liu L, Zhou HY, He L, Song JW, Nie WX, Su ZY. Measurement of urinary $\mathrm{S} 100 \mathrm{~B}$ protein levels and lactate/creatinine ratio in early detection of neonatal hypoxic-ischemic encephalopathy. World J Pediatr. 2006; 4:270-275.

39. Williams CE, Mallard C, Tan W, Gluckman PD. Pathology of perinatal asphyxia. Clin Perinatol. 1993;20(2):305-325.

40. Kinoshita H, Imamura T, Maeda H, et al. Brain hypothermia therapy for neonatal hypoxic ischemic encephalopathy with a severely elevated serum creatine kinase level. Fukushima J Med Sci. 2015;61(1): 54-57.

41. Ojha RK, Singh SK, Batra S, Sreenivas V, Puliyel JM. Lactate: creatinine ratio in babies with thin meconium staining of amniotic fluid. BMC Pediatr. 2006;6:13.

42. Nagdyman N, Komen W, Ko H, Müller C, Obladen M. Early biochemical indicators of hypoxic-ischemic encephalopathy after birth asphyxia. Pediatr Res. 2001;49(4):502-506.

43. Beken S, Aydın B, Dill Di, et al. Can biochemical markers predict the severity of hypoxic ischemic encephalopathy? Turk J Pediatr. 2014; 56(1):62-68.
Neuropsychiatric Disease and Treatment

\section{Publish your work in this journal}

Neuropsychiatric Disease and Treatment is an international, peerreviewed journal of clinical therapeutics and pharmacology focusing on concise rapid reporting of clinical or pre-clinical studies on a range of neuropsychiatric and neurological disorders. This journa is indexed on PubMed Central, the 'PsycINFO' database and CAS,

\section{Dovepress}

and is the official journal of The International Neuropsychiatric Association (INA). The manuscript management system is completely online and includes a very quick and fair peer-review system, which is all easy to use. Visit http://www.dovepress.com/testimonials.php to read real quotes from published authors. 